\title{
Atypical presentations of primary genital syphilis in HIV-negative homosexually active men: a case series
}

\author{
Milan D. BJEKIĆ ${ }^{1 *}$, Milica D. MARKOVIĆ ${ }^{1}$, Sandra B. ŠIPETIĆ ${ }^{2}$ \\ ${ }^{1}$ City Institute for Skin and Venereal Diseases, Belgrade, Serbia \\ ${ }^{2}$ Institute of Epidemiology, School of Medicine, Belgrade University, Belgrade, Serbia \\ ${ }^{*}$ Correspondence: Milan BJEKIĆ, E-mail: milinkovski@gmail.com
}

UDC 616.972-055.3

VERSITA

\begin{abstract}
We report four cases of primary syphilis of the penis in HIV-negative men having unprotected insertive oral sexual intercourse with men. Patients presented with atypical penile lesions mimicking genital herpes, balanitis, lichen planus and fixed drug eruption. Syphilis should be considered in the differential diagnosis of other genital diseases, both sexually or non-sexually transmitted. Considering the increasing incidence of atypical manifestations of syphilis, serological tests for syphilis should also be performed more often.
\end{abstract}

\section{Key words}

Syphilis; Syphilis Serodiagnosis; Penile Diseases; Sexual Behavior; Homosexuality, Male

$P_{\mathrm{d}}^{\mathrm{r}}$ rimary genital syphilis in men is clinically detectable after an incubation period of about of 3 weeks. A typical syphilitic chancre is a sharply demarcated, painless, indurated ulcer with a smooth base and rolled margins, usually more than $0.5 \mathrm{~cm}$ in diameter. Primary syphilitic lesions may affect any area of the skin or mucous membranes, but usually appear on genitals, often situated in the coronal sulcus in men and are frequently associated with nontender bilateral regional adenopathy. However, the majority of genital syphilitic lesions in the primary stage are misdiagnosed, because of atypical presentations (1).

The outbreak of early syphilis cases occurred among men who had sex with men (MSM) from March to June, 2010 in Belgrade.

Herein, we describe four cases of primary syphilis in HIV-negative homosexual men who visited the City Institute for Skin and Venereal Diseases, all with penile lesions and regional lymphadenopathy. All patients reported unprotected insertive oral sex with unknown partners one month before referral to our Institute.
Following the initial clinical assessment, the diagnosis of primary syphilis was confirmed by positive serological tests: nontreponemal test (Venereal Disease Research Laboratory -VDRL) and specific Treponema Pallidum Hemagglutination Assay (TPHA). Dark filed microscopy of primary lesions was not performed due to technical limitations. Patients were treated with a single dose of intramuscular benzathine penicillin G, 2.4 million units. During the follow up, lesions resolved in all patients within the next 20 days posttreatment.

\section{Case reports}

\section{Case 1}

A 30 year-old man presented with multiple, painless penile ulcers which appeared approximately 20 days after insertive oral sex. He was referred to our Institute with the diagnisis of genital herpes by his general practitioner. The lesions first appeared as red macules, which ulcerated by the time the patient was referred to the Institute, so at the examination he presented 
with a dozen of small grouped ulcers on the prepuce and glans penis (Figure 1.). Physical examination revealed enlarged and painful regional lymph nodes, but there were neither general symptoms nor other skin/mucous lesions. The patient's personal history did not indicate any previous sexually transmitted infections (STIs). Serological tests for syphilis were positive: VDRL (titer 1:8) and TPHA test.

\section{Case 2}

A 25 year-old man presented with multiple, painless, shallow erosions on the prepuce and glans penis with mild circular lymphangitis above the coronal sulcus and enlarged, nontender regional lymphadenopathy (Figure 2.). His personal history showed that erosions with crusts first appeared 3 weeks after insertive oral sex. The initial erosions and crusts were already treated by a dermatologist with saline dressing and topical antibiotic cream for two weeks, and then the patient was referred to our Institute as balanoposthitis. The lesions remained unchanged during this time. Physical examination revealed no other skin lesions. Serological tests were routinely performed and revealed positive TPHA with VDRL titer 1:4.

\section{Case 3}

A 31 year-old man presented with two erythematous, lichen planus-like papules on the penile shaft (Figure 3.). The lesions appeared 4 weeks before referral, coexisting with nontender, inguinal lymphadenopathy and remained unchanged during that period. Moreover, at physical examination, lesions were still papular, non-ulcerated, while nongenital skin and mucous membranes were intact. The patient's personal history revealed an episode of primary genital syphilis in 2006, that was successfully treated in our Institute. Serological tests were performed, and VDRL test was positive with titers 1:16, with TPHA test being positive as well.

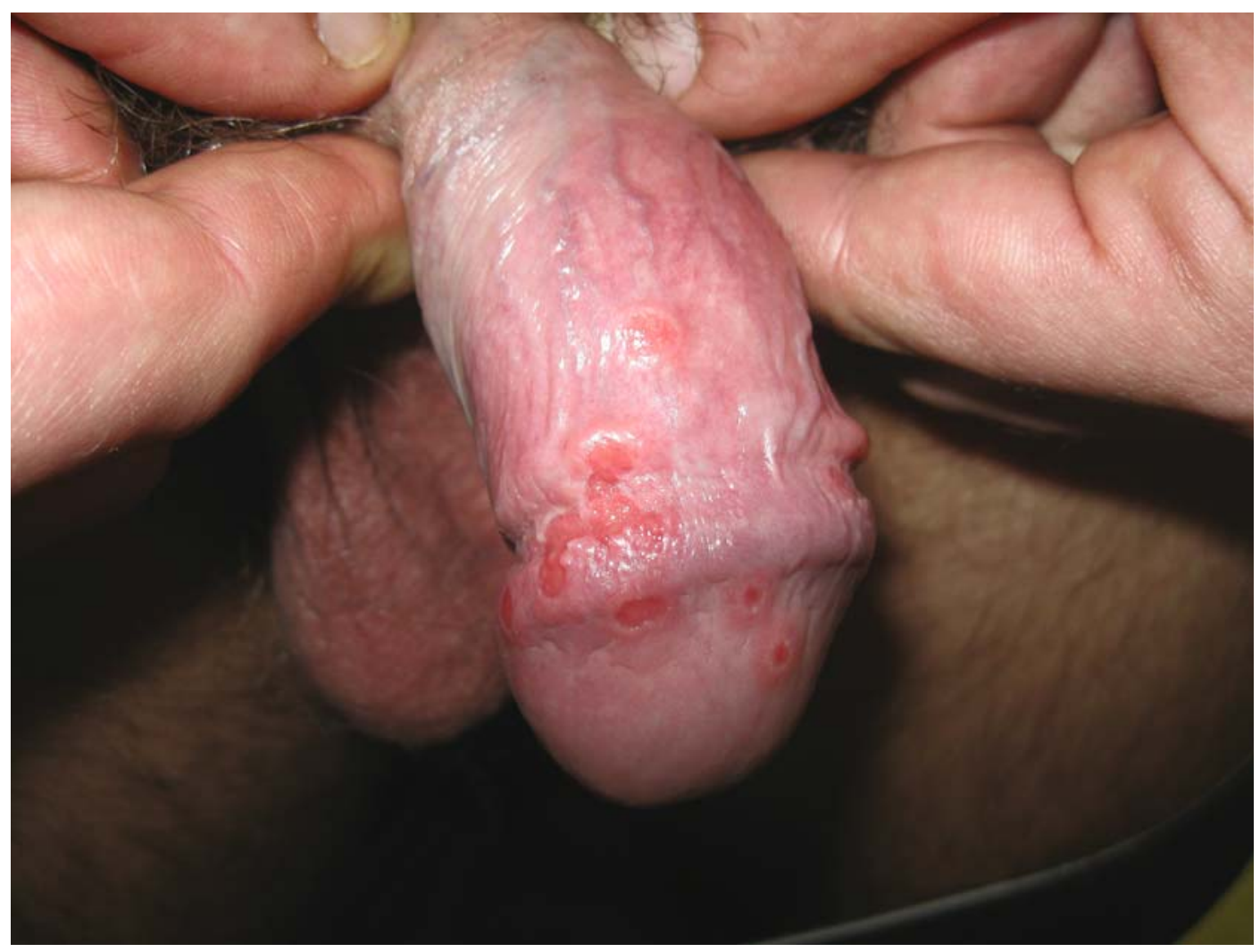

Figure 1. A dozen of nonindurated, herpetiform, sharply marginated ulcers on the prepuce and glans penis, coalescing to irregular ulcerated lesions in the coronal sulcus 


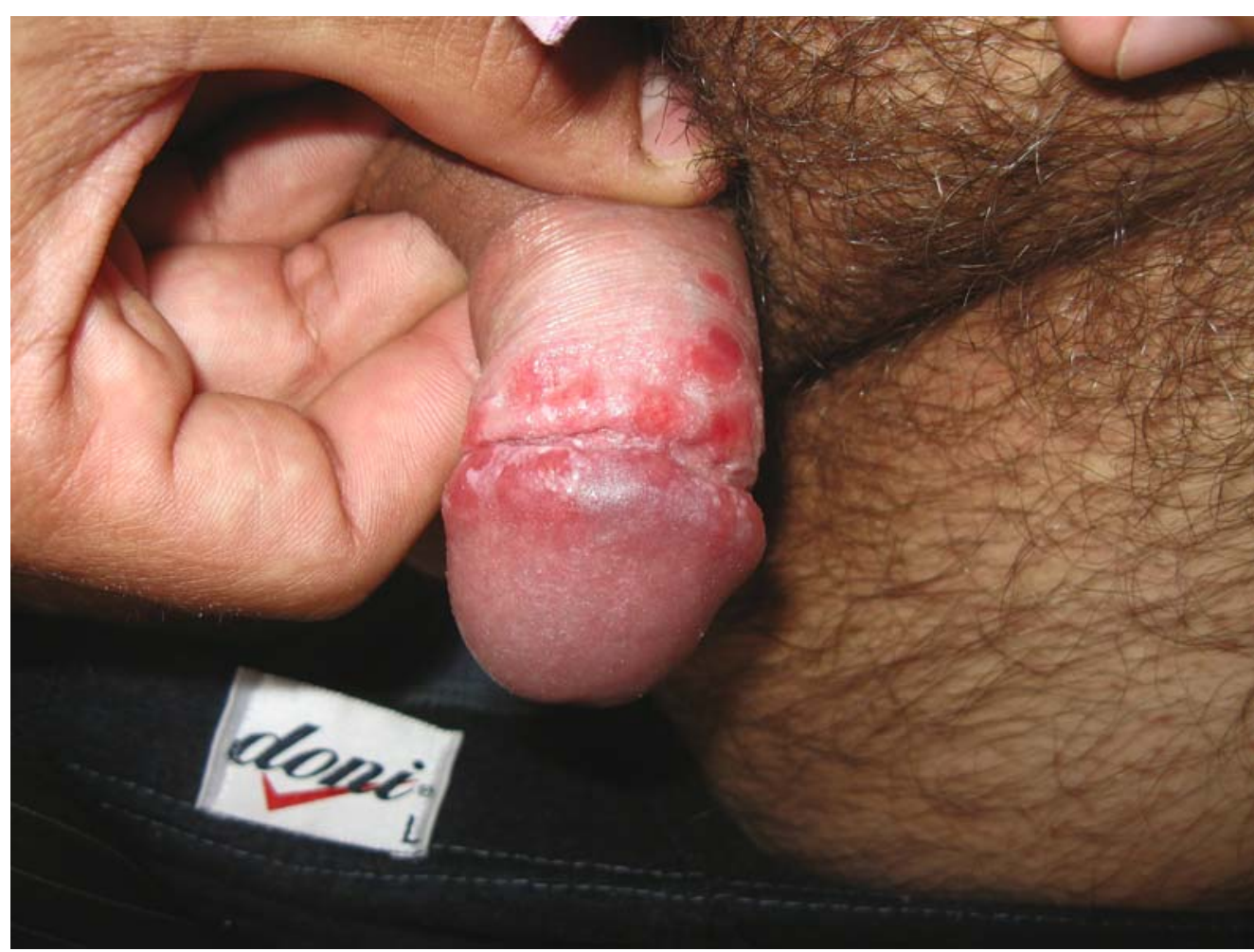

Figure 2. Multiple superficial erosions, mainly of circular distribution over the coronal sulcus on the prepuce and glans penis

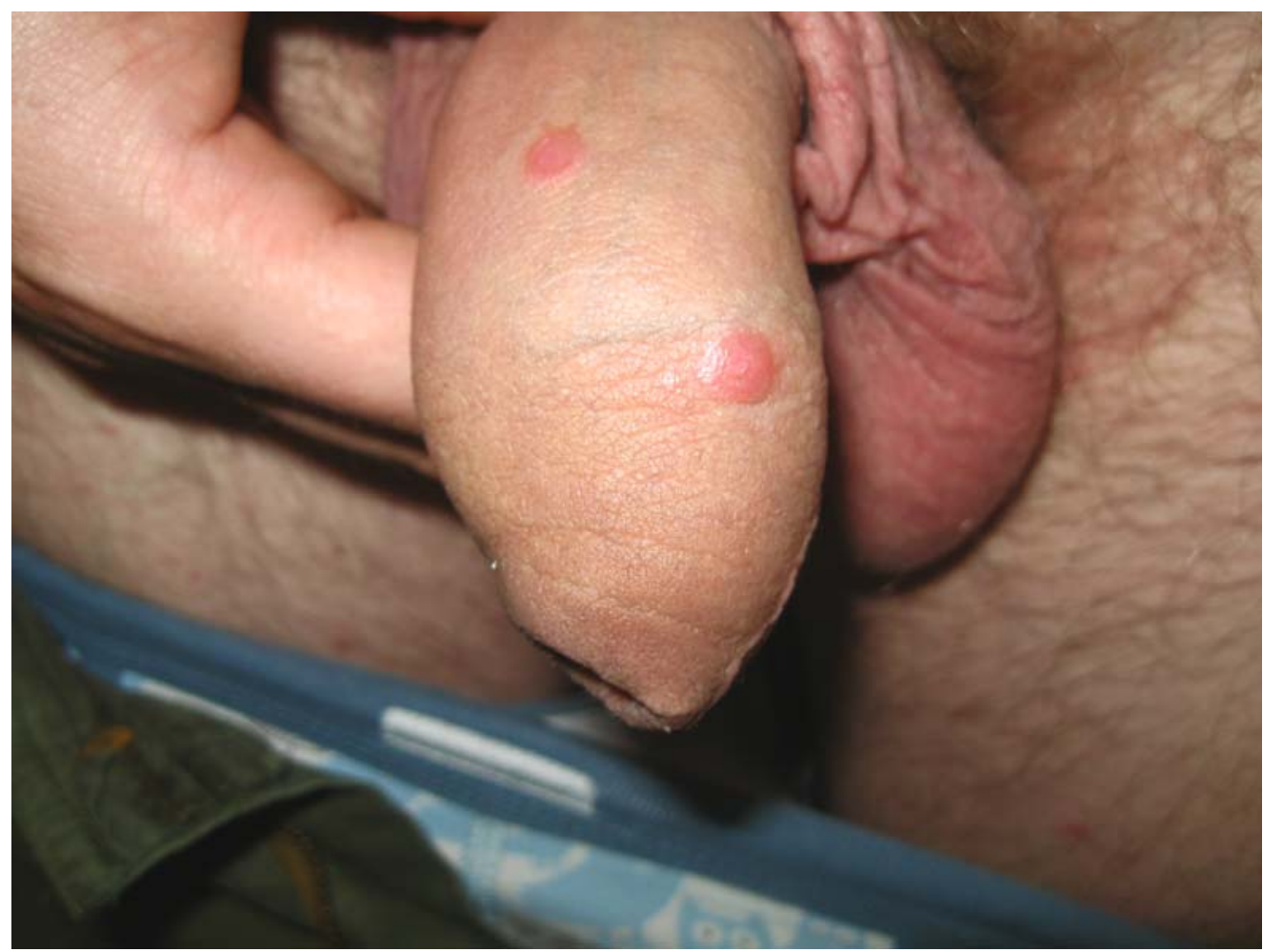

Figure 3. Lichenoid pink shiny papules on the shaft of the penis 


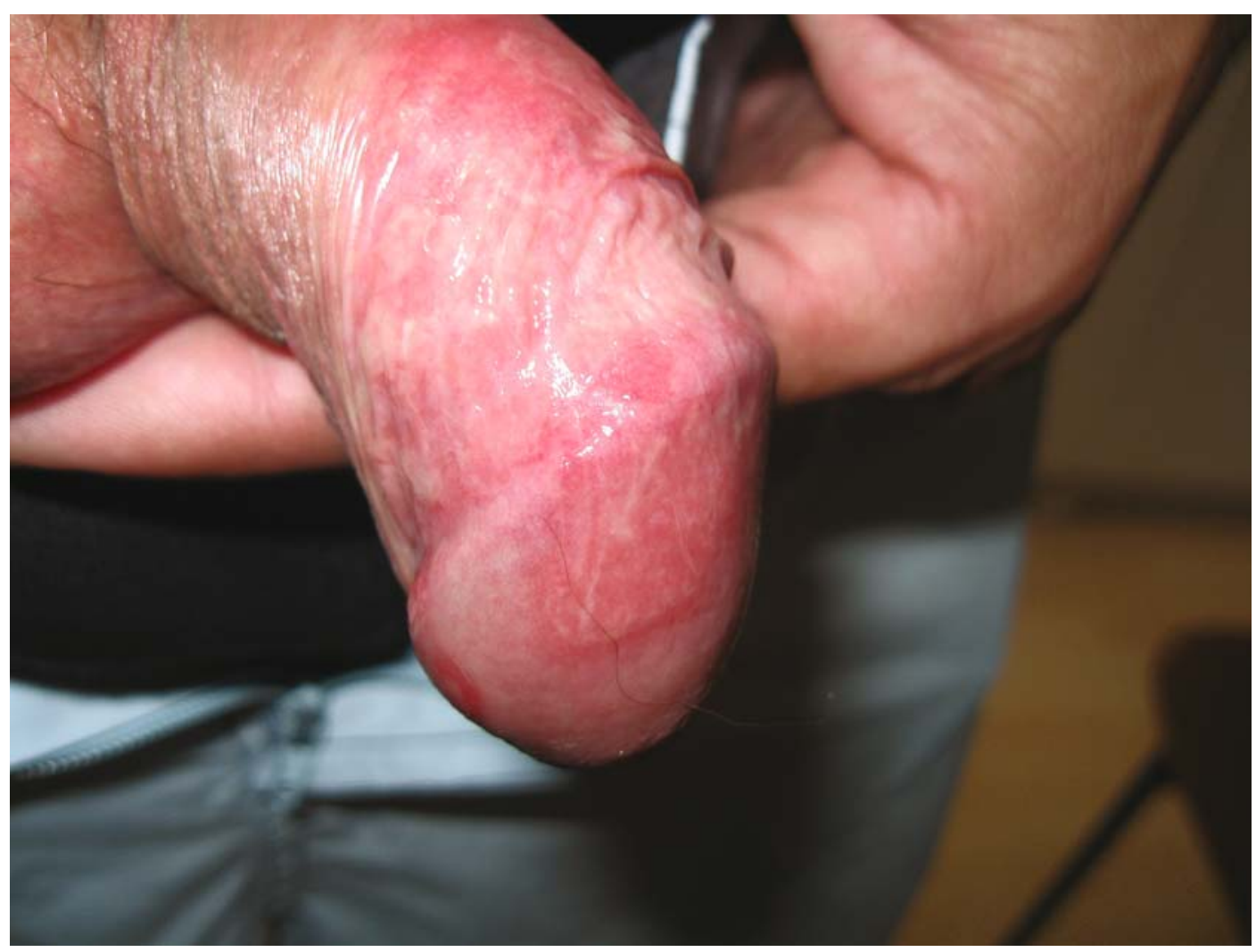

Figure 4. Two out of three erythematous patches, partly eroded with a mild superficial whitish exudate

\section{Case 4}

A 39 year-old man was referred to our Institute due to persistent erosions on the prepuce and glans penis, which appeared two weeks before referral. The examination revealed three moist superficial erosions. The largest measured $3 \mathrm{~cm}$ in diameter, all covered with whitish exudate, accompanied by bilateral, nontender inguinal lymphadenopathy (Figure 4.). Before referral, the patient was pretreated with a topical antimycotic cream. The lesions were painless, clinically resembling fixed drug reaction; however the patient's history did not indicate any drug intake during the previous month. VDRL titer was 1:2, with TPHA test being positive as well.

\section{Discussion}

Genital ulcer disease in male patients can be a sign of a variety of sexually transmitted diseases such as syphilis, chancroid, genital herpes, lymphogranuloma venereum, but may also be a presentation of inflammatory disorders like lichen planus, Reiter's and
Behçet's syndrome, aphthosis, fixed drug eruption, traumatic wounds and even malignancies.

In developing countries, genital ulcer disease is mainly caused by Haemophilus ducreyi and T. pallidum $(2,3)$, while in Europe it is usually caused by herpes simplex virus (HSV) infection, predominantly HSV type 2 (4). In developed countries, the leading cause of genital ulcers in heterosexual men and women remains herpes virus infection; however, primary syphilis is the most common cause in the etiology of genital ulcer among MSM (5).

The incidence of early syphilis in Serbia has decreased in the last three decades (6). The exception was the outbreak of syphilis in 2001, which occurred in an institution for health care of adults with mental disorders (7). Chancroid has not been reported since, and the exact prevalence of genital herpes in Serbia remains unknown, since reporting this infection is not mandatory.

Due to low incidence of syphilis, physicians often fail to diagnose it, especially in patients with atypical 
clinical presentation. Two of four cases presented in this paper were misdiagnosed and treated as genital herpes or balanoposthitis, while the remaining two cases had a misleading clinical appearance of penile fixed drug eruption and lichen planus like lesions.

In the study of DiCarlo and Martin (1) only 31\% of males appeared with the classic syphilitic chancre. It is not infrequent that initial presentation occurs with multiple ulcers resembling genital herpes or chancroid (8). Multiple chancres and other atypical presentations are usually associated with HIV coinfection (9). All cases reported in this paper were HIV negative.

The increasing popularity of oral sex, as a safer sex practice in the HIV era, introduced this type of sexual intercourse as the replacement for higher risk behaviors, especially for MSM population (10). One third of MSM, who were involved in syphilis outbreaks in Brighton and Manchester, United Kingdom, acquired syphilis through oral sex (11). There was also a syphilis outbreak in our Institute from March to June, 2010. Out of the total of 20 diagnosed syphilis cases, 10 were with primary genital syphilis transmitted through insertive oral sex. Multiple genital ulcers were observed in 6 cases, and they may be explained by numerous small penile injuries, from using teeth during oral sex, as sites of $T$. pallidum inoculation.

In all presented cases, serological tests showed lower VDRL titers, already described in primary syphilis (12), and confirmatory TPHA tests, all reactive. Serological test results have limited the sensitivity during the early stage of syphilis, while nontreponemal tests usually become positive 4 to 5 weeks after infection. In our report, the highest titer was in syphilis relapse (VDRL $1: 16)$ which is in agreement with the results of Fiumara (13), who also reported higher titers of antibodies to $\mathrm{T}$. pallidum during the relapse.

Complex clinical and serological diagnosis of syphilis and increase in atypical clinical presentations, emphasize the importance of continuous education of non-experienced physicians, especially in countries with lower incidence of syphilis. Lack of proper and early diagnosis of syphilis, apart from the consequences of delayed or inadequate therapy, has a great impact on increased risk for HIV transmission.
Finally, our paper supports the need for education of the sexually active population, especially MSM, about safe sex practice, stressing the fact that unprotected oral sex is a risk factor for various sexually transmitted infections including syphilis and HIV.

\section{Acknowledgement}

This study was supported by the Ministry of Science and Technology of the Republic of Serbia, through Contract No. 175402 (2011-2014).

\section{References}

1. DiCarlo RP, Martin DH. The clinical diagnosis of genital ulcer disease in men. Clin Infect Dis 1997;25:292-8.

2. Behets FM, Andriamiadana J, Randrianasolo D, Randriamanga R, Rasamilalao D, Chan CY, et al. Chancroid, primary syphilis, genital herpes, and lymphogranuloma venereum in Antananarivo, Madagascar. J Infect Dis 1999;180:1382-5.

3. Ahmed HJ, Mbwana J, Gunnarsson E, Ahlman K, Guerino C, Svensson LA, et al. Etiology of genital ulcer disease and association with human immunodeficiency virus infection in two Tanzanian cities. Sex Transm Dis 2003;30:114-9.

4. Pebody RG, Andrews N, Brown D, Gopal R, De Melker H, François G, et al. The seroepidemiology of herpes simplex virus type 1 and 2 in Europe. Sex Transm Infect 2004;80:185-91.

5. Hope-Rapp E, Anyfantakis V, Fouéré S, Bonhomme P, Louison JB, de Marsac TT, et al. Etiology of genital ulcer disease. A prospective study of 278 cases seen in an STD clinic in Paris. Sex Transm Dis 2010;37:153-8.

6. Federal Institute of Statistics. Demographic statistics. Belgrade: Federal Institute of Statistics: 1972-2004.

7. Vlajinac H, Sipetic S, Bjekic M, Savcic G, Marinkovic J. Outbreak of early syphilis in an institution for the care of adults with mental disorders. Epidemiol Infect 2006;134:585-8.

8. Lacey HB, Higgins SP, Graham D. An outbreak of early syphilis: cases from North Manchester General Hospital. Sex Transm Infect 2001;77:311-3.

9. Lynn WA, Lightman S. Syphilis and HIV: a dangerous combination. Lancet Infect Dis 2004;4:456-66.

10. Centers for Disease Control and Prevention (CDC). Transmission of primary and secondary syphilis by oral sex - Chicago, Illinois, 1998-2002. MMWR Morb Mortal Wkly Rep 2004;53: 966-8.

11. Communicable Disease Surveillance Centre. Increased transmission of syphilis in Brighton and Greater Manchester among men who have sex with men. Commun Dis Rep CDR Wkly 2000;10: 386.

12. Anderson J, Mindel A, Tovey SJ, Williams P. Primary and secondary syphilis, 20 years` experience. 3: Diagnosis, treatment and follow up. Genitourin Med 1989;65: 239-43.

13. Fiumara NJ. Reinfection primary, secondary, and latent syphilis: the serologic response after treatment. Sex Transm Dis 1980; 7 : 111-5. 


\section{Atipična prezentacija primarnog genitalnog sifilisa kod HIV- negativnih seksualno aktivnih homoseksualca: serija prikaza}

\section{Sažetak}

Serija prikaza: Prikazujemo četiri HIV-negativna pacijenta sa primarnim genitalnim sifilisom koji su infekciju dobili nakon nezaštićenog insertivnog oralnog seksa sa nepoznatim muškim osobama. Lezije na penisu su imale atipičnu prezentaciju i podsećale na herpes genitalis, balanitis, lichen planus i erytema fixum.
Diskusija: $\mathrm{O}$ sifilisu bi trebalo razmišljati u diferencijalnoj dijagnozi kako polnih bolesti, tako i drugih dermatoza genitalne regije.

Zaključak: S obzirom na sve češće atipično ispoljavanje sifilisa, potrebno je češće uraditi i serološke reakcije na sifilis.

\section{Ključne reči}

Sifilis; Serodijagnoza sifilisa; Bolesti penisa; Seksualno ponašanje; Muška homoseksualnost 